\title{
SUSTAINABILITY OF SEAHORSES: LESSONS LEARNED OF LOCAL WISDOM FROM BINTAN ISLANDS, RIAU ISLANDS PROVINCE
}

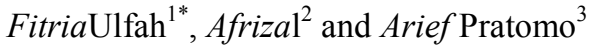 \\ ${ }^{1}$ Social Economic of Fisheries Department, Marine Science and Fisheries Faculty, Raja Ali Haji \\ Maritime University, Tanjung Pinang 29111, Indonesia \\ ${ }^{2}$ Public Administration Department, Social and Political Science Faculty, Raja Ali Haji Maritime \\ University, Tanjung Pinang 29111, Indonesia \\ ${ }^{3}$ Arief Pratomo, Marine Science Department, Marine Science and Fisheries Faculty, Raja Ali Haji \\ Maritime University, Tanjung Pinang 29111, Indonesia
}

\begin{abstract}
Seahorse (Hippocampus spp.) has a high economic value in Bintan Island that leads to its exploitation by coastal community intensively. This study was to assess local knowledge on seahorse ecology which was captured across shoreline near the coastal communities. The research was conducted in SebongPereh village Bintan Island. The data were collected by conducting depth interviews and focus group discussion on seahorse fishermen which was selected purposively. The results revealed local fishermen have ecological knowledge related to habitat types, behavior, and monthly variation in abundance, size and reproduction pattern. The result also showed that the existence of the seahorse during the catch season moves around, follow the condition of the seaweed and tidal of sea water. This local knowledge was used by fishermen as a strategy in determining the fishing time and catchment area of a seahorse. Through such local wisdom, local fishing communities established a local institution to manage conversation and sustainability use of seahorse in waters of SebongPereh village.
\end{abstract}

\section{Introduction}

One of the coastal areas in Riau Islands Province is Bintan Island. Bintan Island has a large coastal area, with many marine biological resources that have high economic value. One of the most valuable economic resources in Bintan Island is the seahorse (Hippocampus spp.[16], or commonly known as "ondok-ondok" by the local community. The existence of seahorse is mostly found in SebongPereh Village, District, Bintan Regency[14].

SebongPereh village was chosen as study area. Interestingly, in this site, the existence of seahorses was almost repeatedly observed from January to May in each year [14]. In that 
season, many people are turning the profession into a seahorse catcher due to the higher value of the selling price of dried seahorses that reaches more than 5 million rupiahs $/ \mathrm{kg}$. Even when the catch season is over - according to the fishermen - the price of dry seahorse can reach 7 million rupiahs $/ \mathrm{kg}$. The high value of the seahorse had driven it catchment by Bintan Island's fishing community intensively. This condition makes the species more vulnerable to overexploitation [14].

However, although the price of seahorses is quite promising, not everyone can take a seahorse in considerable numbers. This is because the experience and the ability to distinguish between a seahorse and sea grass[2], mangroves [15], coral reefs [12], the roots of seaweed or sand[7],[11], becomes the determinant of how many seahorses can be captured. Other skills that are also needed are the diving skills of the fishermen, as well as knowledge of the right time to dive.This condition made not every fisherman can obtain optimal results, even though at that time there were many seahorses in the waters of SebongPereh Village.

Therefore, the knowledge and experience of fishermen in taking the seahorse became one of the keys successes in obtaining a considerable catch.A few studies about local knowledge has been conducted, but with another species such as dugong. Based on that result study, the local knowledge supported the development of appropriately targeted management strategies [17], [6]. This means seahorses could improve the welfare of the community if the fisherman has sufficient knowledge of the management and utilization of the seahorse itself. Such knowledge includes fishing time, fishing gear, catching ways, the condition of seahorse when captured and ecological conditions of seahorse fishing. Based on these conditions and to be better understand the impacts of the harvesting and trade of seahorse requires knowledge of their biology, along with population monitoring and fisheries management [4].So it is necessary to conduct research to obtain information about local knowledge of local communities on seahorses. The aim of this study was to assess the extent of fishing community understanding on seahorse ecology in SebongPereh village which was captured across shoreline near their village.

\section{Materials and methods}

\subsection{Study area}

The research was conducted in SebongPereh Village, BintanIsland, and Riau Island Province. The study has been done on February - September 2017.

\subsection{Survey design and methodology}

Primary data were obtained from in-depth interviews using question guides to key informants[13]. Primary data were also obtained from Focus Group Discussion (FGD) on seahorse fishermen in SebongPereh village. The data was taken in this research consists the number of catches, capture frequency, catch time, fishing gear, the condition of seahorse when it catches, ecological condition of a catchment area, and sale price of a seahorse. While the secondary data obtained from the journal and other relevant references.

The data was collected from 3 key informants and 15 respondents. The technique to determine key informants and respondentsin this study were conducted purposively based on information from the village community. The key informant in this study was the fishermen who got the most catches. While the respondents were those who did the catch in the water sea of SebongPereh. Data analysis is done by using a qualitative approach, by condensing, display data that have been processed, drawing and verifying conclusions[8]. 
The validity of data is done by comparing data obtained from the key informant with the result of discussion through Focus Group Discussion (FGD) until information is saturated[8], [10].

\section{Results and discussion}

\subsection{Time and catch frequency}

According to the fishermen, time of catches the seahorses in SebongPereh village was usually done in January until June, with the highest catches in February and March. In the $4^{\text {th }}$ month, the number of seahorse catches reaches twice more than the $1^{\text {st }}$ month, but lower than in the $3^{\text {rd }}$ month. This information was then evaluated through the score table by making the $1^{\text {st }}$ month (January) as benchmark comparison $\left(h_{o}\right)$. Furthermore, fishermen mentioned that the highest time of peak season is not always same every year, but depends on the seasons

Table 1.Table of comparison of seahorsecatches ${ }^{\mathrm{a}}$

\begin{tabular}{|c|c|c|c|c|c|c|c|c|c|c|c|}
\hline \multicolumn{12}{|c|}{ Month } \\
\hline 1 & 2 & 3 & 4 & 5 & 6 & 7 & 8 & 9 & 10 & 11 & $12^{\mathrm{b}}$ \\
\hline $1 \mathrm{x}$ & $3 x$ & $3 x$ & $2 x$ & $1 x$ & $1 x^{c}$ & - & - & - & - & - & - \\
\hline
\end{tabular}

The fishermen usually catch the seahorsein low tide condition until it will tide between 2-3 hours. In one month, they usually catch the seahorse \pm 14 days. They only catch the seahorse in the morning until afternoon.According to the fishermen, in the time toward high tide, the seahorse is relatively easier to be found in the sea than at low tide. It's also easier to found the seahorse at low tide and rainy, compared to when the sea at low tide and sunny. In fishermen perception, at that time, they observed that the seahorse was known to come out from a coral reef, also from the hole of the seabed.According to the fishermen opinion, perhaps it was caused by the temperature and the content of the sea water effects to the presence of the seahorses.

\subsection{The number of catches}

The amount of the seahorses in one catch was variousdepend on the catch season. In the $1^{\text {st }}$ month (January), fishermen could catch about $20-35$ seahorses per catch, or around $150-350$ seahorses in a week, or around $300-500$ in a month. While in the $2^{\text {nd }}$ and $3^{\text {rd }}$ month, the fishermen could catch the seahorse between in range of $50-70$ seahorses in once catch, or around $250-500$ seahorses in a week. But there were also fishermen who can catch up reached 100 seahorsesat once. Probably, the differences of the experience and knowledge among the fishermen resulted in various catch rate individually. When the amount of catch quantified in weight, at the peak season (in the $2^{\text {nd }}$ and $3^{\text {rd }}$ month), the fishermen could get as much as $2 \mathrm{~kg}-4 \mathrm{~kg}$ dry seahorse. While in another month, the fishermen could get the dry seahorsein range of $1-2$ kilograms.

\subsection{Catchment area: habitat condition}


According to the fishermen, the seahorses were found around brown macroalgae, Sargassum sp. This seaweed was known by the local community as a "rengkam". Furthermore, it was mentioned that seahorses were also found around the seagrass (or known as "setu") although relatively in small amounts. The seahorses more often found in sargassum at the edge of lagoon situated up to $200 \mathrm{~m}$ towards the beach. Seahorses or commonly known as "ondok-ondok" by local people were also found, likely, around reef crest where the fishermen mentioned it "siring tubir". The fishermen recognized "Siring tubir" is a part before reef slope. Usually around "siring tubir" there were corals, sargassumspp, and gorgonian (Antipathes spp.) or "akarbahar". Typically, seahorses that found around the seagrass were generally a type of seahorse that has crown and dark colored (Figure 1).

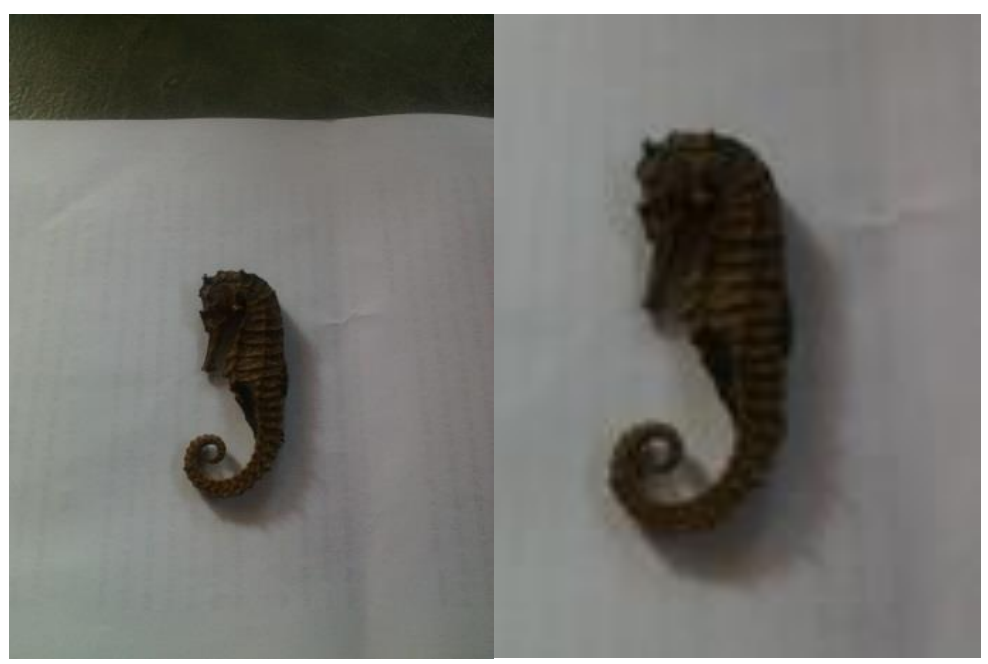

Fig.1. Types of seahorse often found in seagrass

Whereas the seahorse that commonly found around Sargassumsp were seen as a yellow horse (Figure 2). The seahorses that were often found in seagrass at seawater of SebongPereh were Hippocampus spinosissmus, H. histrik, and H. kuda[17]. While those found around the Sargassumsp were H. barbouri and hippocampus comes. The possibility of seahorses mentioned by fishermen included into these species[4]. 


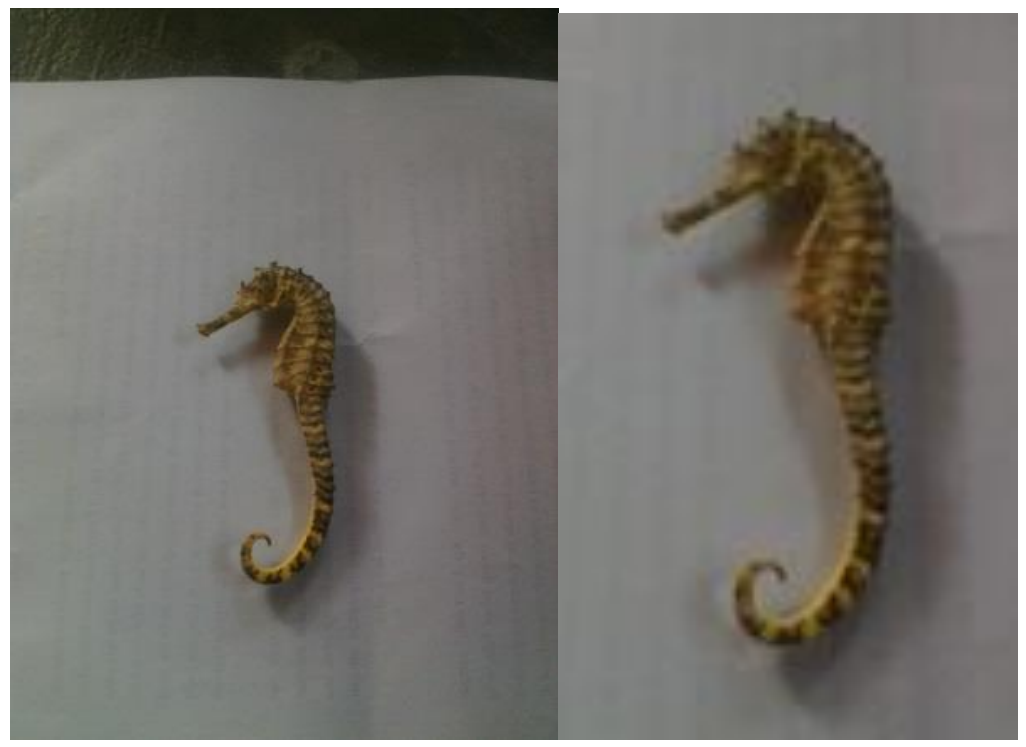

Fig. 2. Types of seahorse found in the Sargassumsp

\subsection{Monthly variation patterns}

Based on the explanation of fishermen, on the first month (January) macroalgae"rengkam" in the lagoon waters are still in abundance and long lifeform condition (Fig. 3). In this month, the sea waves were strong enough, so that seahorses were found relatively tend in the base of themacroalgae.

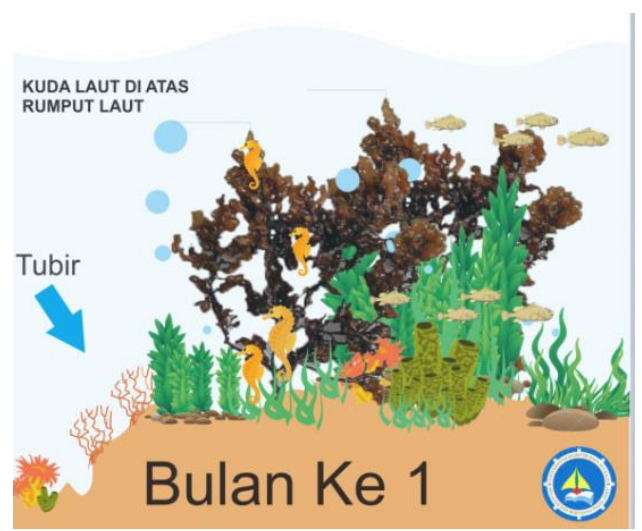

Fig.3.Illustration of seahorses in January

On the $2^{\text {nd }}$ month (February), strong wave cause sargassumat the base began breakage, so that, there were no leaves. This cause the fishermen have to dive deeper in order to get a seahorse because it commonlyfound in the base of the sargassum. Fishermen also said that on the $3^{\text {rd }}$ month (March) some parts of the sargassumwere fallen, some even begin to rot. In this month the seahorsewas found at the base of thesargassum, above it, or in the fallen sargassumthat has not been rotten yet. 


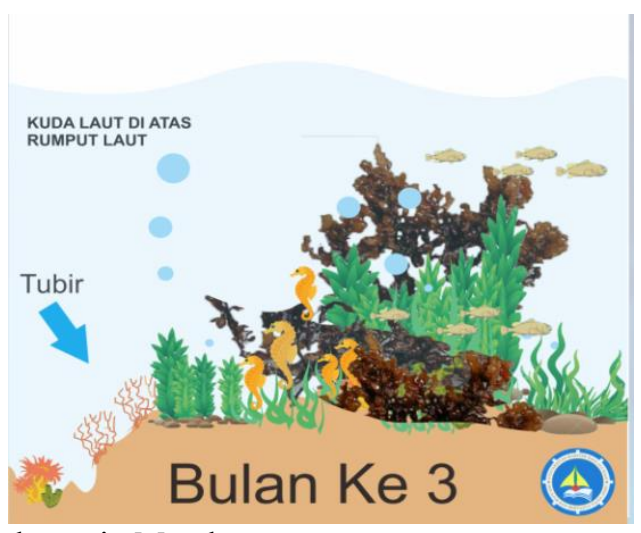

Fig. 4 Illustration of seahorse in March

According to the fishermen, sargassumthat has fallenmeans it has broken onto the coral reef so that the base and top of the sargassum were in parallel position. Broken sargassumusuallydoes not drift. It will rot on the rock until it is destroyed. While the driftingsargassum usually is a sargassumthat has broken away because of strong waves. The rotten sargassumis a sargassum that has been fallen and tendshas blackcolour.

In April the fallen sargassum are increasing. In this month, the seahorse could be found at the base, at the end, in a broken sargassum but not rotten yet, even in a rotten sargassum but not totally decomposed. In May, sargassum starts to run out or clear.In this case, most of Sargassumhas been fallen and rotten, even destroyed. At this time, it began difficult to find the seahorse, but still could found it at the base of sargassum, inside the broken sargassum, in a rotten sargassum, even some of it was found in a coral reef.

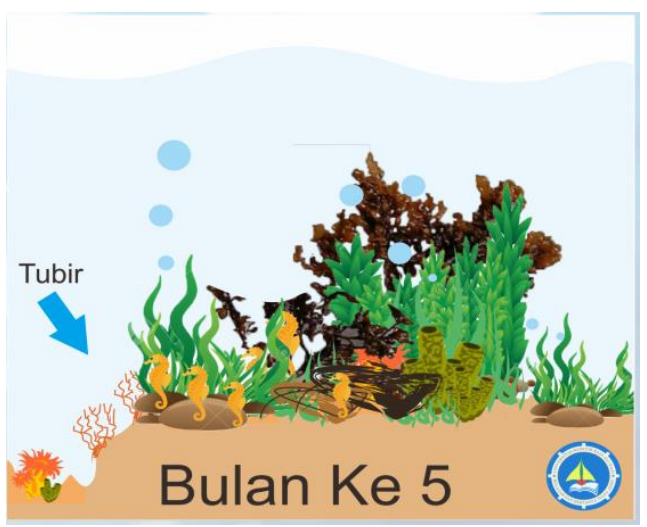

Fig. 5. Illustration of seahorse in May

In the $6^{\text {th }}$ month (June), the sargassumswere getting worn out and clean, increasingly difficulty to find seahorse in SebongPerehVillage waters. This condition continues in the $7^{\text {th }}$ month. In the $9^{\text {th }}$ month, the sargassum began to grow again and progressively longer until the $12^{\text {th }}$ month. But in the $12^{\text {th }}$ month, the windwas so strong and so do the seahas waved.This condition made the sargasssum "berabuk". "Berabuk" is the local conception about sargassum condition when the leaves of sargassumwere covered up by the substrate.

\subsection{Condition and behavior of seahorse}


Fishermen mentioned that in the second month (February), they often found seahorses in the pregnant conditions. The number of pregnant seahorses in one catch reaches almost $70 \%-80 \%$. It means if the number of seahorses that have been caught reached 30 seahorses, as much as $21-24$ seahorses were in pregnant conditions. They also could found seahorse in a pregnant condition in another month, but not as much as in the $2^{\text {nd }}$ month. Thisinformation was collected from the fishermen using score table by making the $1^{\text {st }}$ month (January) as benchmark comparison $\left(\mathrm{h}_{\mathrm{o}}\right)$. Furthermore, in this month fishermen also frequently observed found when the seahorse wastransferring their eggs to each other.

Table 2. Table of comparison the amount of seahorse catches in pregnant condition ${ }^{\mathrm{s}}$

\begin{tabular}{cccccccccccc}
\hline \multicolumn{10}{c}{ Month $^{\text {b }}$} \\
\hline 1 & 2 & 3 & 4 & 5 & 6 & 7 & 8 & 9 & 10 & 11 & 12 \\
\hline $1 \mathrm{x}$ & $3 \mathrm{x}$ & $2 \mathrm{x}$ & $1 \mathrm{x}$ & $1 \mathrm{x}$ & - & - & - & - & - & - & - \\
\hline
\end{tabular}

${ }^{\mathrm{a}}$ Primary data

${ }^{\mathrm{b}}$ Month in a year

${ }^{\mathrm{c}}$ Comparison result with the $1^{\text {st }}$ month as a benchmarks

\subsection{The distribution of seahorse}

The fishermen use a hook and sunglasses to getthe seahorse. The hook used to drill down the sargassum, or local people say it "memusing". But they use hand to pick the seahorse. While the sunglasses were used to protect the eyes of fishermen when they dived. Furthermore,the fishermen mentioned that theseahorses were sold to collectors who come to SebongPerehvillage. But there were also fishermen who sell directly to the collector which is located in the market town of Tanjungpinang. Then the collectors sell the seahorses to overseas market. But until now, the fishermen do not havequota capture letter of the seahorse.They must have this letter because seahorses are listed as vulnerable or endangered on the 2003 IUCN Red List of Threatened Species [4], [5].Officially,in Indonesia the trading of the seahorse is regulated by the Ministry of Environment and Forestry by issuing quotas of capture and export quota [4].

\subsection{Local wisdom: local management institutionalization}

SebongPerehvillage seahorse fishermen already have the initiative to form a group of seahorse fishermen. But this group will only be officially instituted in thecoming year (2019). They - encouraged by Government Agent of Coastal and Marine Resource Management (BalaiPengelolaanSumberdayaPesisirdanLaut Padang/BPSPL Padang) havealso created a marine protected area through Village Regulation[4].The area of conservation is about 15 ha (Fig. 6). 


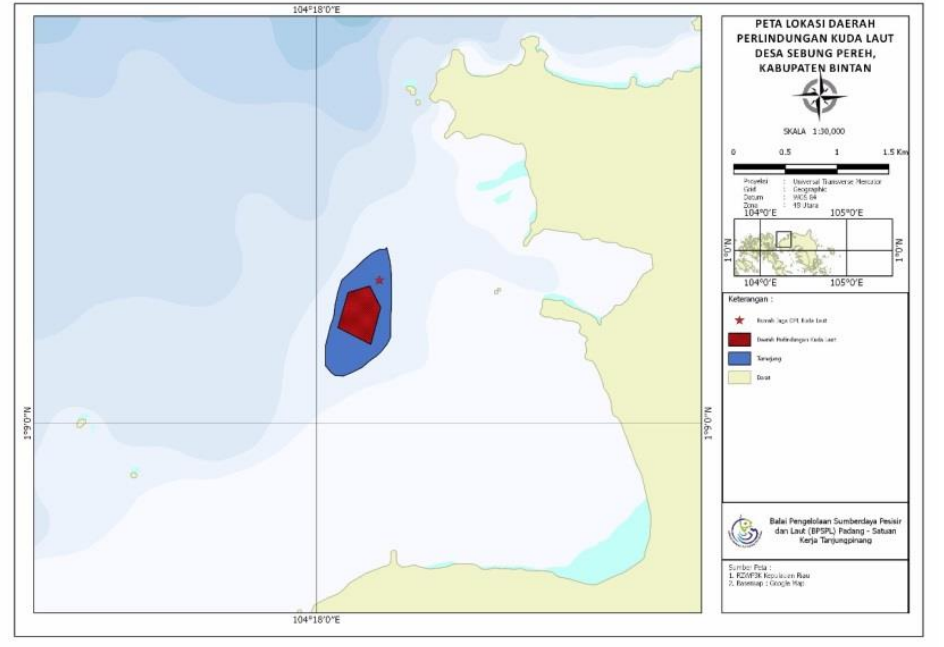

Fig. 6. Marine protected area of seahorse at SebongPerehvillage

As for the provisions on the conservation area is the fisherman is prohibited to make arrests in the conservation area. If a fisherman catches 1 (one) seahorse in a conservation area, then the fisherman is required to return 3 (three) seahorses to the area. Unfortunately, until now there have been no enforcement sanctions given if there are fishermen who violate the rules.In addition to the absence of sanctions for offenders, the SebongPereh Village fisherman has not yet placed supervisors in the conservancy area, even though there are already supervisory huts.

\section{Conclusions}

The results revealed that based on experience and daily observations, fishermen have quite complex the ecology knowledge to effectively utilize the seahorse as an important source of income from the waters of SebongPereh village. Seahorse fishing and related environmental knowledge can be used to development and implementation of sustainable it uses. Nevertheless, lack of best management practices could lead to the endangered of this types of fisheries. More consultation at interdisciplinary frontiers is needed in order to formulate practical solutions to the core problems of Bintan seahorse fishing community in the future.

The authors wish to thank the KEMENRISTEK DIKTI program for research funding, Dr. Syakti for re-reading the manuscript, community of SebongPereh village, and our students for technical support and research campaigns, Raja Ali Haji Maritime University.

\section{References}

1. BalaiPengelolaanSumberdayaPesisirdanLaut Padang [Internet]. Available from :http://bpsplpadang.kkp.go.id/bpspl-padang-dan- 
$\underline{\text { nelayan-bintan-utara-menginisiasi-dpl-kudaluat-seluas-15-hektar }}$ (2017).

2. Bell EM, Lockyear JF, McPherson JM, Dale MA. \& Vincent ACJ. Environmental Biology of Fishes 67,35 - 46 (2017).

3. Cullen-Unsworth LC, Jones BL, Seary R, Newman R, Unsworth RKF. Marine Pollution Buletin11 (007) (2017)

4. Foster SJ, Vincent ACJ.Journal of Fish Biology 65, 1-61 (2004).

5. Harasti D, Martin-Smith K, Gladstone W. Journal of Fish Biology 85, 1413 - 1428 (2017).

6. Hashim M, Ito S, Numata S, Hosaka T, Hossain MS, Misbari S, Yahya NN, Ahmad S. Marine Policy 78:18-25 (2017).

7. Kuiter RH. Seaford: Aquatic Photographics (2017)

8. Miles MB, Huberman AM, Saldana J. USA: Sage Publications (2017)

9. Mulyawan AE, Saokani J. Journal BalikDiwa. 6 (2z0:13 - 19(2017)

10. Moleong LJ. RemajaRosdakarya (2017)

11. Moreau MA, Vincent ACJ. Marine and Freshwater Research 55, 231 - 239. (2014)

12. Perante NC, Pajaro MG, Meeuwig JJ, Vincent ACJ. Journal of Fish Biology 60,821 - 837 (2002)

13. Pratomo A, [Thesis]. Retrieved from Bogor University of Agriculture(2005)

14. Rabiansyah. SebongPereh Maritime University(2005)

15. Rosa IL, Oliveira TPR, Castro AL C, Moraes L, Xavier JHA, Nottingham MC, Dias TLP, Bruto-CostaLV, Araujo ME, Birolo AB, Mai ACG, Monteiro-Neto C. Neotropical Ichthyology 5,405-414 (2007)

16. Santoso. JurnalSaintekPerikanan2(1 )2006:83-93(2006)

17. Simanjuntak CF. [Skripsi]. Retrieved from Raja Ali Haji Maritime University. (2015)

18. Vincent ACJ, Marsden AD, Evans KL \& Sadler LM. Behaviour 141, $141-156(2004)$ 